\title{
Two New Species of Eriophyoid Mites (Prostigmata: Eriophyidae) Infesting Acacia Trees from Egypt
}

\author{
A. S. EL-HALAWANY \\ Fruit Acarology Dep., Plant protection Research Institute, ARC, Dokki, Giza, Egypt
}

\begin{abstract}
Two new eriophyoid mite species were found in Egypt. They were described and illustrated as Tetra ibrahimi sp. nov. and Aculops tanani sp. nov. They were collected from Acacia nilotica (L.) Delile (Fabaceae). Both species are vagrants on the undersurface of leaves and pods causing rusting symptoms.
\end{abstract}

Key words: Eriophyoidea, Taxonomy, New species, Aculops, Tetra, Acacia nilotica.

\section{INTRODUCTION}

The genus Tetra was established by Keifer, 1944 based on the type species Phyllocoptruta concave Keifer, 1939. It differs from other genera in the Anthocoptini by its prodorsal shield with frontal lobe and without spines projecting from anterior, scapular tubercles on rear shield margin, scapular setae usually directed divergently posterior and without posterior plate; dorsal opisthosoma not flat, without thickened bands and with a wide mid-dorsal longitudinal furrow; all coxal setae present; and legs with usual series of setae (Amrine $e t$ al., 2003).

Up to date, Tetra includes 104 species worldwide, 31 species from Fabaceae. Among them, two species infesting Acacia trees; one of them was reported in Egypt (Meyer, 1992; Abou-Awad \& Elsawi, 1993 and de Lillo \& Amrine 2011).

The genus Aculops was established by Keifer, 1966, based on the type species Vasates populivagrans (Keifer, 1953). It is similar to Aculus Keifer, 1959; but differs as follows: in Aculops, the prodorsal shield frontal lobe is small, and the top is sharp and acute and often with one spine; in Aculus, the prodorsal shield frontal lobe is broader, the top is round or blunt and often with two or four spines (Amrine et al., 2003).

Up to date, Aculops includes 157 species among them 30 species infesting Fabaceae plants, including three species infesting Acacia trees. One of them was recorded in Egypt (Meyer \& Ueckermann, 1990; Elhalawany, 2014 and Xie \& Wang 2013). Three species of Aculops recorded in Egypt (i.e. Aculops lycopersici (Tryon, 1917), A. nilotica Abou-Awad, 1979 and A. awadi El-halawany, 2014).

Two new species collected on Acacia nilotica (L.) Delile (Fabaceae). Both species are vagrants on the undersurface of leaves and pods causing rusting symptoms.

\section{MATERIALS AND METHODS}

Sampling was carried out irregularly from July 2012 to August 2014 including plant foliages, branches, flowers and buds in Qalyubia, Gharbia and Menoufia governorates in Egypt. Specimens of the eriophyoid mite were collected from plants by direct examination using stereo-microscope. Slides were mounted with Keifer's F-medium according to protocol reported in Amrine \& Manson, 1996. Drawings were made according to de Lillo et al., 2010 and abbreviations follow Amrine et al., 2003. The morphological terminology used herein follows that of Lindquist (1996) and the generic classification is based on Amrine et al. (2003). Specimens were measured following de Lillo et al. (2010). For each species, the holotype female measurement precedes the corresponding range for paratypes (given in parentheses). For males, only the range of measurements is given. All measurements are given in micrometers $(\mu \mathrm{m})$. The count of ventral opisthosomal semiannuli starts from the first full semiannulus behind the coxae II. Dorsal opisthosomal semiannuli are counted from the first full semiannulus behind the middle of the prodorsal shield rear margin. Host plant names and their synonymies are in accordance with the plant list online database (2010).

\section{TAXONOMY}

Family: Eriophyidae Nalepa, 1898.

Subfamily: Phyllocoptinae Nalepa, 1892.

Tribe: Anthocoptini Amrine \& Stasny, 1994.

Genus: Tetra Keifer, 1944. ES14.

Tetra ibrahimi sp. nov. (Figs. 1\& 2)

\section{Description:}

Female: $(\mathrm{n}=10)$. Body fusiform, $190(170-210)$ including gnathosoma, 48 (46 -52) wide, 50 (50 -54) thick; white-yellowish. Gnathosoma $20(20-23)$, projecting obliquely downwards, pedipalp coxal setae (ep) 4 (4-5), dorsal pedipalp genual setae 


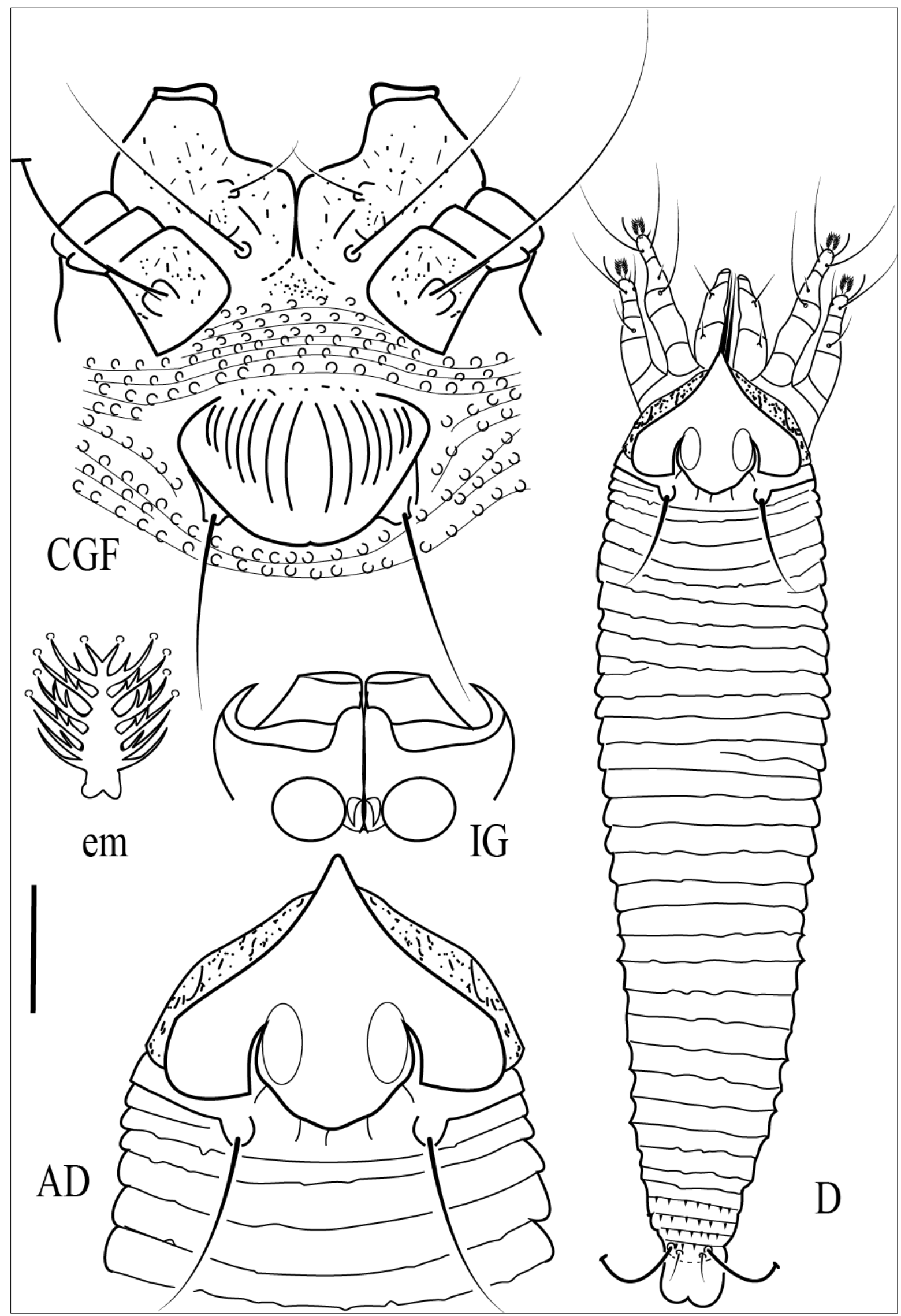

Fig. (1): Semi-schematic line drawing of Tetra ibrahimi sp. nov.: D- dorsal view of female; AD- prodorsal shield; em-empodium; CGF- female coxae and genitalia; IG- female internal genitalia. Scale bar: $20 \mu \mathrm{m}$ for $\mathrm{D} ; 10 \mu \mathrm{m} \mathrm{D}, \mathrm{CGF}, \mathrm{AD} ; 5 \mu \mathrm{m}$ for em. 


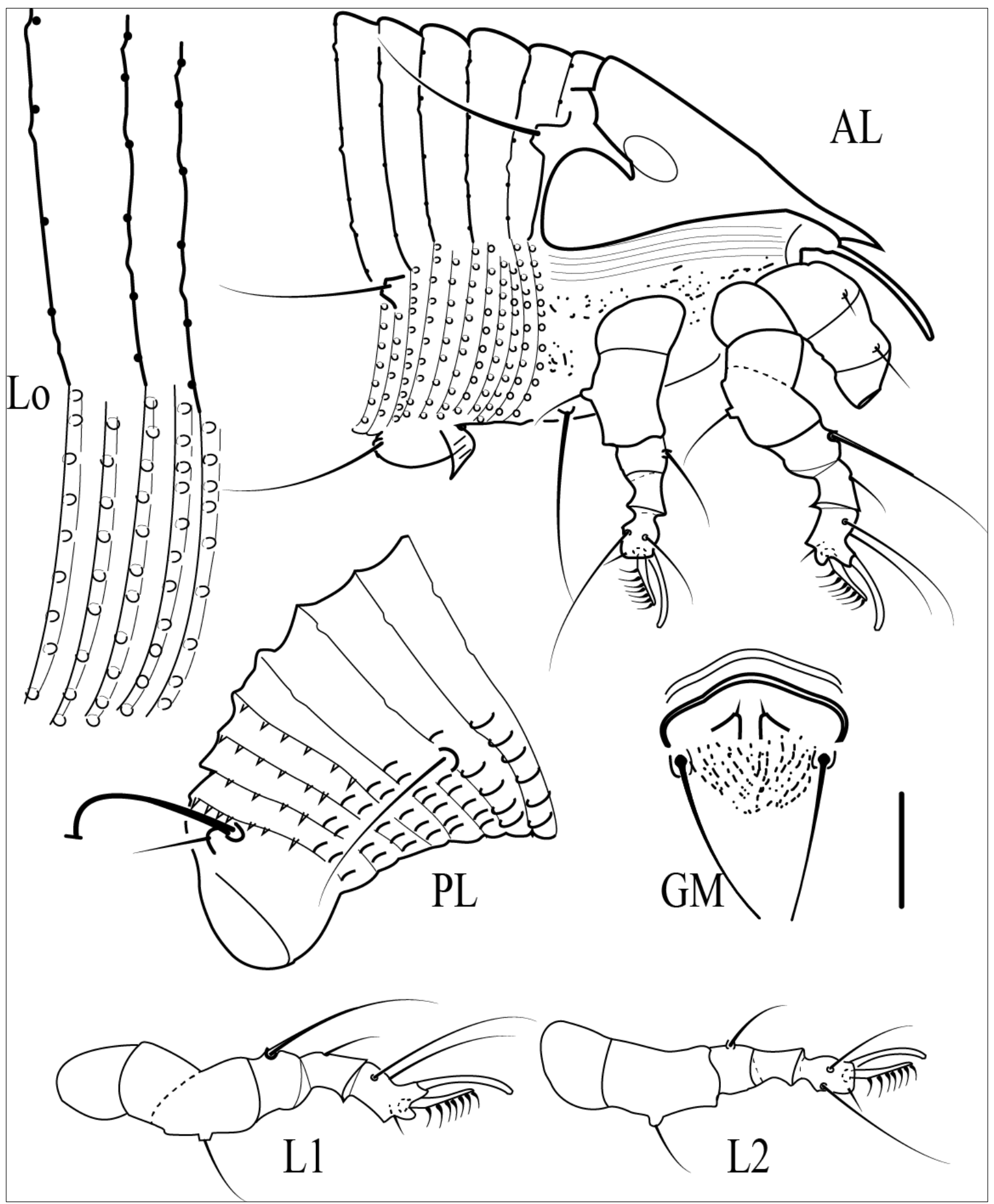

Fig. (2) Semi-schematic line drawing of Tetra ibrahimi sp. nov.: AL- antero-lateral view of female; Lomicrotubercles in lateral view; PL- postero-lateral view of female; GM- male genitalia; L1- Leg I; L2leg II. Scale bar: $20 \mu \mathrm{m}$ for AL, PL, GM, L1, L2.

(d) 6 (6 -7), chelicerae 17 (17-19). Prodorsal shield 30 (29-31) including frontal lobe 38 (37-40) wide; sub-triangular in anterior shape with a broad base and distally triangular frontal lobe anterior-medially 6 (5-7) over gnathosomal base; prodorsal shield unornamented of incomplete short median line and admedian lines, connected between dorsal tubercles with submedian lines ahead of anterior dorsal tubercles, faint elliptical shape connected with admedian line at $1 / 3$ prodorsal shield. Scapular tubercles on rear shield margin, 22 (21-23) apart, scapular setae $(s c) 22(20-23)$ projecting backward. Coxigenital region with 6 (5-6) semiannuli between coxa and genital coverflap. Coxal plates with granules and dashes; setae (1b) 7 (7-8), 10 (10-11) apart; setae (1a) 19 (18-20), 9 (8-9) apart; setae (2a) 
28 (25-30), 21 (21-23) apart. Prosternal apodeme 5 (5-6). Opisthosoma dorsally arched, with 35 (34-36), with 56 (55-60) narrow ventral semiannuli (counted from the first annulus after the coxae II), smooth dorsal semiannuli and the last 4 dorsal semiannuli with spines on rear margin; circular microtubercles set on posterior part of ventral semiannuli; last 8 ventral semiannuli with elongated and liner microtubercles; in lateral view pointed microtubercles on dorsal annulus. Setae $c 220$ (1724), 47 (45-48) apart, on ventral semiannulus 10 (10 $11)$; setae $d 38$ (37-40), 38 (37-38) apart, on ventral semiannulus 22 (22-24); setae e 10 (9-10), 18 (1718) apart, on ventral semiannulus 32 (31-33); setae $f$ 27 (27-30), $20(20-23)$ apart, on $7^{\text {th }}$ ventral semiannulus from rear; setae $h 15$ (5-6), setae $h 267$ (63-85). Female genital cover flap 15 (12-15), 201(20-22) wide, with 14 (14-16) longitudinal ridges, with one transverse line granules at base of cover flap, proximal setae on coxisternum III ( $3 a) 15$ (14-15), 15 (14-15) apart.

Leg I 30 (30-32), femur 9 (8-9), basiventral femoral setae $(b v) 10(10-11)$; genu 5 (4-5), antaxial genual setae $\left(l^{\prime \prime}\right) 25$ (23-25); tibia 6 (5-6), paraxial tibial setae ( $l$ ) 5 (5-6), located 1/3 from dorsal base, tarsus 6 (5-6), paraxial, fastigial, tarsal setae $\left(f t^{\prime}\right) 17$ (15-17), antaxial, fastigial, tarsal setae $\left(f t^{\prime \prime}\right) 26$ (2426), setae ( $\left.u^{\prime}\right) 4$ (3-4); tarsal empodium (em) 7 (7-8), simple, 7-rayed, tarsal solenidion ( $\omega) 9$ (8-9) distally tapered.

Leg II 25 (25-27), femur 8 (8-9), setae (bv) 11 $(11-12)$; genu $4(4-5)$, setae $\left(l^{\prime \prime}\right) 10(9-11)$; tibia 5 (5$6)$, tarsus 5 (5-6), setae $\left(f t^{\prime}\right) 8(8-10),\left(f t^{\prime \prime}\right) 20(18-22)$, setae $\left(u^{\prime}\right) 4$ (3-4); tarsal empodium (em) 6 (6-7), simple, 7-rayed, tarsal solenidion $(\omega) 8$ (8-9) distally tapered.

Male: $(\mathrm{n}=5)$. Similar to female; body fusiform, 170 (160-185) long, 46 (44-47) wide, 47 (46-48) thick. Prodorsal shield 32 (32-34)long, 37 (36-37) wide; Scapular tubercles on rear prodorsal shield margin, 20 (19-20) apart, scapular setae (sc) 17 (16-18) projecting backward. Opisthosoma with 34 dorsal semiannuli and with 55 (55-57) ventral semiannuli. Male genitalia 19 (19-20) wide, 13 (13-14), setae (3a) 14 (12-14), 13 (13-14) apart.

\section{Type material:}

Holotype, female (slide no. EGPErio46.1) from Acacia nilotica (L.) Delile (Fabaceae), Qalyubia Egypt, $30^{\circ} 14^{\prime} \mathrm{N}, 31^{\circ} 15^{\prime} \mathrm{E}, 5$ July 2012 , Coll. Ashraf El-Halawany, deposited at Fruit Acarology Department Collection, Plant Protection Research Institute (PPRI), Dokki, Egypt.

Paratypes, 10 females and 5 males on 8 slides (slide no. EGPErio46.2-45.10), with the same data as holotype; 5 females on (slide no. EGPErio46.11-
45.15), from Acacia nilotica (L.) Delile (Fabaceae), Egypt Gharbia and Menoufia governorates Egypt, 3 August 2014, Coll. Ashraf El-Halawany, deposited at PPRI, Egypt. 5 slides (4 females and one male) slide number (NJAUAcariEriEgypt13) at the Arthropod/Mite Collection of the Department of Entomology, Nanjing Agricultural University, Jiangsu Province, China; 5 slides (4 females and one male) slide number (AcY:13/366) at the Agriculture Research Council, Plant Protection Research Institute, Biosystematics Division, Pretoria, South Africa (ARC-PPRI).

Host plant: Acacia nilotica (L.) Delile (Fabaceae), common names prickly acacia and gum Arabic.

Relation to the host plant: The mites are vagrants on the undersurface of leaves, flowers and pods causing rusting symptoms.

Etymology: This species was named after the late Prof. Dr. Gamal El-Deen Ibrahim, Head of Fruit Acarology Dep., Plant Protection Research Institute, A.R.C., Egypt.

Differential diagnosis: This new species herein was described compared with all species known from Acacia; similar to Tetra acaciae Abou-Awad \& Elsawi, 1993 described from Acacia nilotica (L.) Delile, in design of prodorsal shield, but differs in having 7-rayed tarsal empodium, the coxal surface with granules and dashes, genital coverflap with 1416 longitudinal lines and granules at base and the last $4^{\text {th }}$ opisthosomal annuli with spines of T. ibrahimi; while tarsal empodium 6-rayed, coxae blank, absolute genital coverflap ridges and all dorsal annuli smooth for T. acaciae. Moreover, this new species is similar to Tetra niloticae Meyer, 1992 from Acacia nilotica (L.) in 7-rayed tarsal empodium, however, prodorsal shield design, opisthosoma dorsal annuli and genital female cover flap different in T. ibrahimi. Also, the new species resembles Tetra bauhiniae Channabasavanna, 1966, described from Bauhinia purpurea L. (Fabaceae) in presenting a 7-rayed empodium, but distinguished by prodorsal shield pattern, fewer opisthosomal semiannuli (34-36 dorsal semiannuli and 55-60 ventral semiannuli) and more than longitudinal ridges of female coverflap 14-16 for T. ibrahimi, versus 52 dorsal semiannuli, 65 ventral semiannuli, genital coverflap 10-12 ridges of T. bauhiniae. [

Genus Aculops Keifer, 1966. B21. Aculops tanani sp. nov. (Figs. 3\& 4)

\section{Description:}

Female: $(\mathrm{n}=6)$. Body fusiform, 195 (190-215) including gnathosoma, 58 (55-62) wide, 60 (58-64) thick; white-yellowish. Gnathosoma 25 (23-27), 
projecting obliquely downwards, pedipalp coxal setae (ep) 4 (3-5), dorsal pedipalp genual setae (d) 6 (6-7),

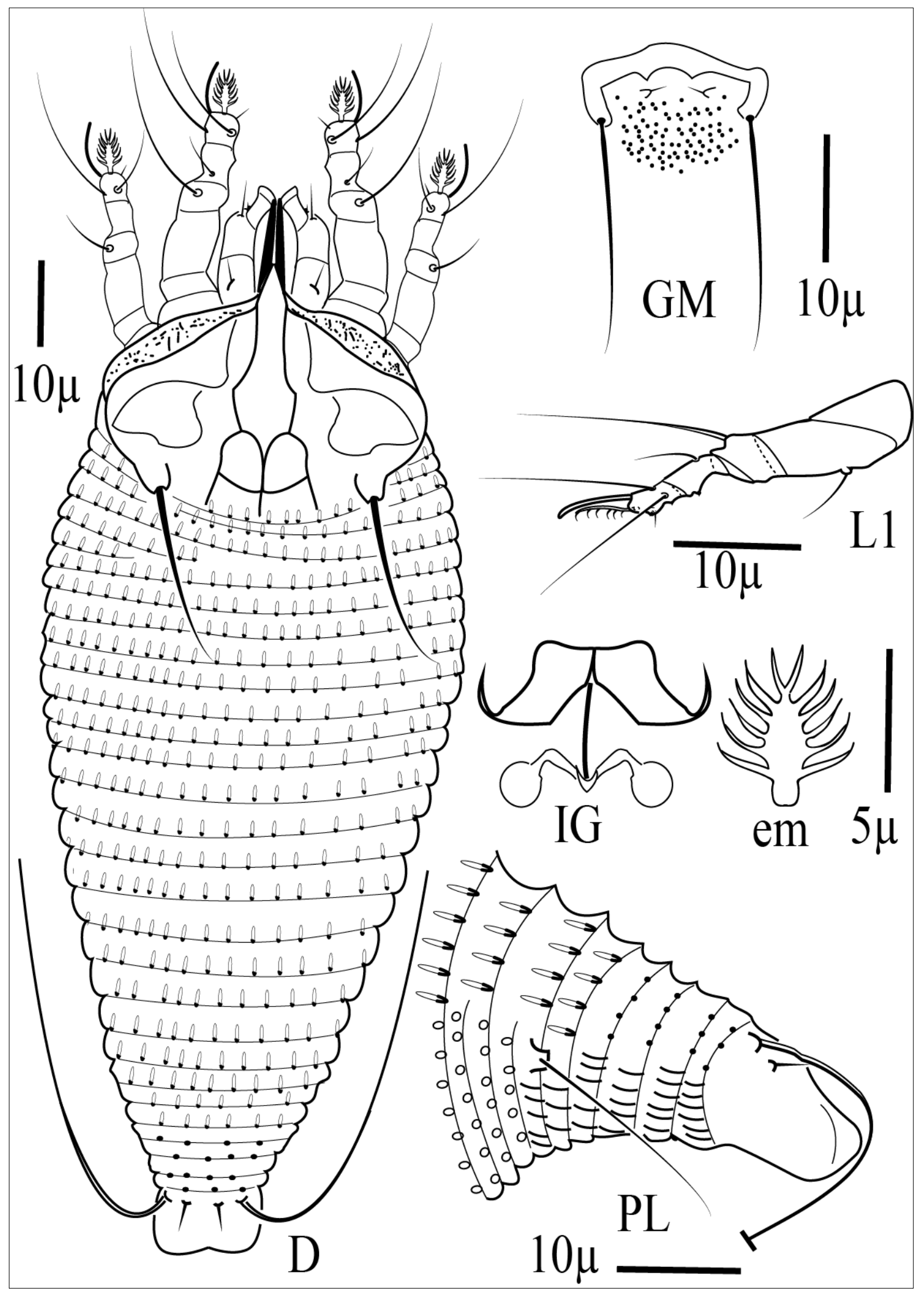

Fig. (3) Semi-schematic line drawing of Aculops tanani sp. nov.: D- dorsal view of female; GM- male genitalia; L1- Leg I; IG-female internal genitalia, em-empodium; PL-postero-lateral view of female. 


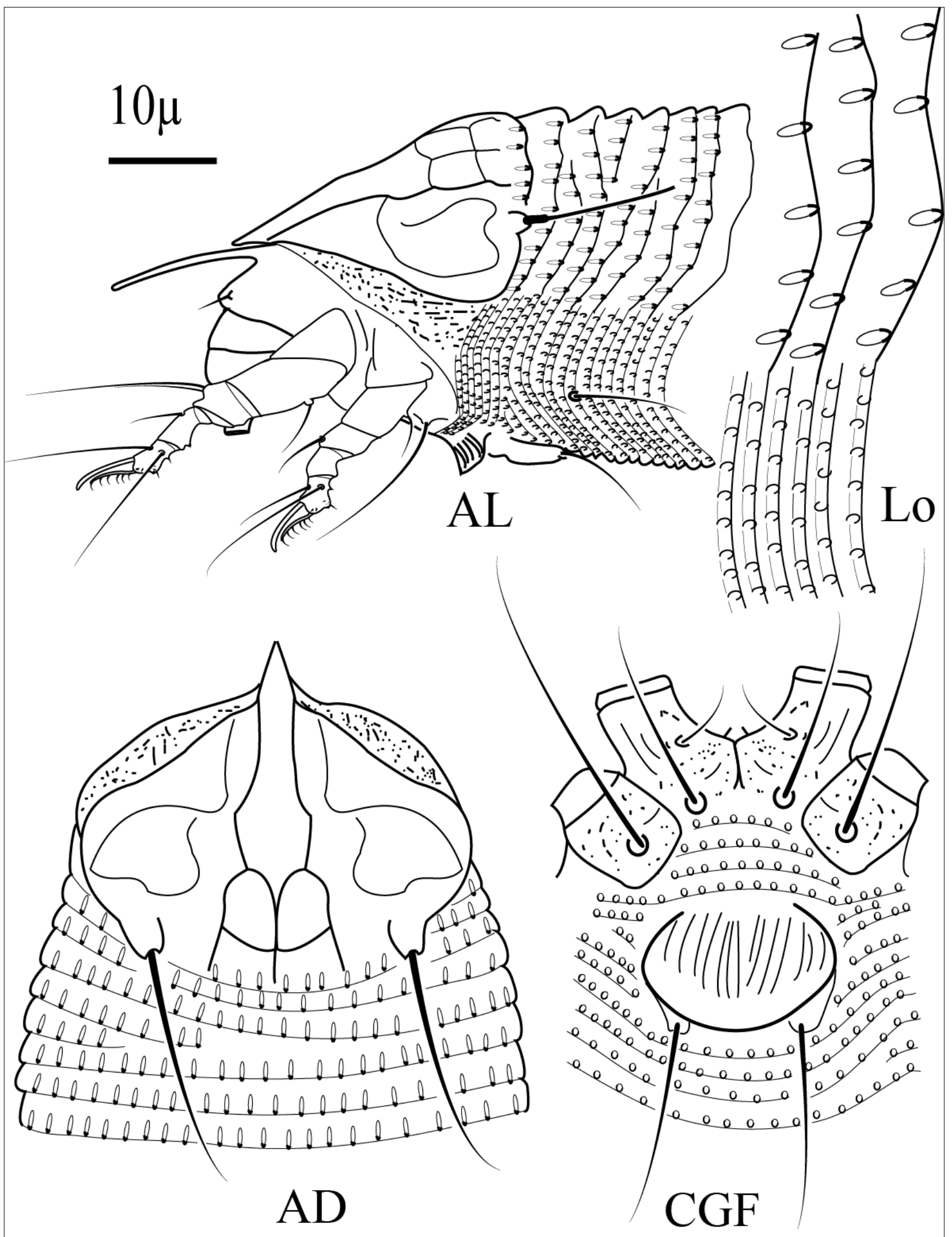

Fig. (4) Semi-schematic line drawing of Aculops tanani sp. nov.: AL- antero-lateral view of female; Lomicrotubercles in lateral view; $A D-$ prodorsal shield; CGF-female coxae and genitalia . Scale bar: $10 \mu \mathrm{m}$ for $\mathrm{AL}, \mathrm{AD}, \mathrm{CGF}$.

chelicerae 19 (19-21). 34 (31-35) including frontal lobe 46 (44-50) wide; sub-triangular in anterior shape with a broad based and distally triangular frontal lobe anterior-medially 5 (4-5) over gnathosomal base; ornamentation of incomplete median line distinct on posterior $2 / 5$ of prodorsal shield, connected to complete admedian lines by transverse lines at $1 / 5$ and $2 / 5$ posterior of prodorsal shield, admedian lines narrowing anteriorly diverging slightly from anterior lobe to cross line at about $2 / 5$ 
prodorsal shield arching lateral and posterial towards rear prodorsal shield margin, submedian line from lateral of anterior lobe running sub-parallel to admedian, forking at about $1 / 2$ of prodorsal shield; the two branches connected by a transverse line anterior of dorsal tubercles, lateral prodorsal shield area with granules and dashes on each side. Scapular tubercles on rear shield margin, 26 (25-27) apart, scapular setae (sc) 22 (20-23) projecting backward. Coxigenital region with 4 (4-5) semiannuli between coxa and genital coverflap. Coxal plates with granules and dashes, setae (1b) 7 (6-7), 11 (10-11) apart; setae (1a) 23 (21-23), 10 (9-10) apart; setae (2a) 30 (30-32), 26 (24-26) apart. Prosternal apodeme 5 (5-6). Opisthosoma dorsally arched, with 28 (28-30) relatively semiannuli, with 54 (52-56) narrow ventral semiannuli (counted from the first annulus after the coxae II), with faint elliptical microtubercles set on the posterior margin of dorsal semiannuli and the last 4 dorsal semiannuli with pointed on rear margin; circular microtubercles set on posterior part of ventral semiannuli; last 6 ventral semiannuli with elongated and liner microtubercles. Setae $c 217$ (15-18), 53 (51-54) apart, on ventral semiannulus 10 (10-11); setae $d 48$ (44-50), 32 (3133) apart, on ventral semiannulus $20(18-20)$; setae $e$ 17 (15-17), 18 (17-18) apart, on ventral semiannulus 32 (31-33); setae $f 30$ (27-30), 21 (19-21) apart, on $6^{\text {th }}$ ventral semiannulus from rear; setae $h 15$ (5-6), setae $h 265$ (55-67). Female genital coverflap 15 (1516), 20 (19-20) wide, with 14 (12-14) longitudinal ridges, proximal setae on coxisternum III (3a) 25 (2326), 15 (14-15) apart.

Leg I 32 (30-33), femur 10 (9-10), basiventral femoral setae (bv) 12 (10-12); genu 5 (4-5), antaxial genual setae $\left(l^{\prime \prime}\right) 21(20-22)$; tibia $6(5-6)$, paraxial tibial setae $(l) 6(5-6)$, located $1 / 3$ from dorsal base, tarsus 6 (5-6), paraxial, fastigial, tarsal setae $\left(f t^{\prime}\right) 17$ (15-18), antaxial, fastigial, tarsal setae $\left(f t^{\prime \prime}\right) 20$ (1921), setae (u') 3 (3-4); tarsal empodium (em) 7 (6-7), simple, 6-rayed, tarsal solenidion $(\omega) 7$ (7-8) distally tapered.

Leg II 30 (27-30), femur 9 (8-9), setae (bv) 12 (11-13); genu 5 (5-6), setae $\left(l^{\prime \prime}\right) 9$ (9-11); tibia 5 (5$6)$, tarsus $5(5-6)$, setae $\left(f t^{\prime}\right) 10(9-11),\left(f t^{\prime \prime}\right) 20(18-$ 20), setae ( $\left.u^{\prime}\right) 3(3-4)$; tarsal empodium ( $\left.\mathrm{em}\right) 7$ (6-7), simple, 6-rayed, tarsal solenidion $(\omega) 7$ (7-8) distally tapered.

Male: $(\mathrm{n}=3)$. Similar to female, body fusiform, 180 (170-190) long, 52 (51-55) wide, 55 (52-60) thick. Prodorsal shield 33 (32-33) long, 44 (42-45) wide; Scapular tubercles on rear prodorsal shield margin, 26 (25-27) apart, scapular setae (sc) 19 (18-19) projecting backward. Opisthosoma with 28 (28-29) dorsal semiannuli and with $52(52-53)$ ventral semiannuli. Male genitalia 18 (17-18) wide, 13 (1314), setae (3a) 25 (24-26), 14 (13-14) apart.

Type material: Holotype, female (slide no. EGPErio45.1) from Acacia nilotica (L.) Delile (Fabaceae), Egypt Qalyubia, 30 ${ }^{\circ} 14^{\prime} \mathrm{N}, 31^{\circ} 15^{\prime} \mathrm{E}, 5$ July 2012, Coll. Ashraf El-Halawany, deposited at fruit Acarology Department Plant Protection Research Institute Dokki Egypt.

Paratypes, 5 females and 2 males on 7 slides (slide no. EGPErio45.2-45.8), with the same data as holotype; 5 slides (4 females and one male) slide number (NJAUAcariEriEgypt14) at the Arthropod/Mite Collection of the Department of Entomology, Nanjing Agricultural University, Jiangsu Province, China; 5 slides (4 females and one male) slide number (AcY: 13/367) at the Agriculture Research Council, Plant Protection Research Institute, Biosystematics Division, Pretoria, South Africa (ARC-PPRI).

Host plant: Acacia nilotica (L.) Delile (Fabaceae).

Relation to the host plant: The mites are vagrants on the undersurface of leaves and pods causing rusting symptoms.

Etymology: The species name "tanani" refers to the name of location village Tanan Qalyobia - Egypt, where the type specimens were collected.

Differential diagnosis: This new species is the second eriophyid species of the genus Aculops found on plants of the Fabaceae family in Egypt as the first one is A. awadi El-halawany, 2014. They can be differentiated from each other as follows: in $A$. acaciae, median and submedian lines absent, tarsal empodium 7-rayed, tarsal solenidion knobbed; opisthosoma with 4 longitudinal subdorsal waxy ridges running the entire somal length, fading to rear. While in A. tanani, median and submedian lines present, tarsal empodium 6-rayed, tarsal solenidion simple; opisthosoma without longitudinal ridges. In addition, the new species differs from Aculops acaciae (Ryke\& Meyer, 1960) in prodorsal shield unornamented, smooth opisthosomal dorsal semiannuli and tarsal empodium 7-rayed in $A$. acaciae. Moreover, this new species is similar to $A$. sepius Xie, 2013, collected from Vicia sepium Linn. (Fabaceae) but differentiated from the latter as follows: in A. sepius, opisthosoma dorsally with round microtubercles, tarsal empodium 5-rayed, female genital coverflap with 12 longitudinal ridges. While in A. tanani, opisthosoma dorsally with faint elongate microtubercles, tarsal empodium 6-rayed and female genital cover flap with 12-14 longitudinal ridges. Also, the prodorsal shield pattern of the new species resembles to Aculops helichrysi Meyer \& Uckermann, 1990, described from Helichysum petiolare H.\&B. (Asteraceae), but differs in that the 
tarsal empodium with 6-rayed, setae $f$ on ventral semiannuls $6^{\text {th }}$ from rear and dorsal opisthosoma with 28-30 ventral semiannuli (in A. helichrysi tarsal empodium 5-rayed, setae $f$ on $4^{\text {th }}$ and opisthosoma dorsal annuli 39 semiannulus).

\section{ACKNOWLEDGMENTS}

Appreciation to Prof Dr. Xue Xiaofeng and Miss. Qiong Wang, for confirming identification and depositing paratypes in the Department of Entomology, Nanjing Agricultural University, Nanjing, Jiangsu, China. Appreciation also to Dr. Eddie Ueckermann, and Dr. Charnie Craemer, for providing many papers used in this study and depositing paratypes in the collection of ARC-PPRI, Biosystematics, Pretoria South Africa. Also thanks to Dr. M. Abou-Setta, PPRI-ARC, Egypt for reviewing the manuscript.

\section{REFERENCES}

Abou-Awad, B. A. 1979. Two new species of genus Aculops in Egypt (Eriophyoidea: Eriophyidae). Acarologia, 21 (2): 234-238.

Abou-Awad, B. A. and Elsawi, S. A. 1993. Two new species of eriophyid mites injurious to Acacia trees from Egypt (Acari, Eriophyidae). Deutsche. Entomol. Z., 40 (2): 403-406.

Amrine, J. W. and Manson, D. C. 1996. Preparation, mounting and descriptive study of eriophyoid mites. In: Lindquist, E.E., Sabelis, M.W. \& Bruin J. (Eds.), Eriophyoid mites: their biology, natural enemies and control. World Crop Pests, 6, Elsevier Science Publishing, Amsterdam, The Netherlands, pp. 383-396.

Amrine, J. W.; Stasny, T. A. and Flechtmann, C. H. 2003. Revised keys to the world genera of the Eriophyoidea (Acari: Prostigmata). Indira Publishing House, West Bloomfield, Michigan, USA, 244 pp.

Channabasavanna, G. P. 1966. A contribution to the knowledge of Indian eriophyid mites (Eriophyoidea: Trombidiformes: Acarina). Univ. Agric. Sci. Hebbal, Bangalore, India, 154 pp.

de Lillo, E. and Amrine, J.W. 2011. Computerized catalog of the Eriophyoidea. In preparation.

de Lillo, E.; Craemer, C.; Amrine, J.W. and Nuzzaci, G. 2010. Recommended procedures and techniques for morphological studies of
Eriophyoidea (Acari: Prostigmata). Experimental and Applied Acarology, 51, 283-307.

EL-Halawany, A. S. 2012. Survey of eriophyid mites on some fruit trees, with re-descriptions of two newly recorded species and a checklist of eriophyid mites in Egypt (Acari: Eriophyoidea). Egypt. Acad. J. biolog. Sci., 5 (2):205 -216.

El-Halawany, A. S. 2014. Aculops awadi, a replacement species name for Aculops acaciae Abou-Awad\& Elsawi (Prostigmata: Eriophyidae). Acarines, 8(1):67.

Keifer, H. H. 1939. Eriophyid studies VII. Bulletin of the California Department of Agriculture, 28: 484-505.

Keifer, H. H. 1944. Eriophyid studies XIV. Bulletin of the California Department of Agriculture, 33: $18-38$.

Keifer, H. H. 1953. Eriophyid studies XXI. Bulletin of California Department of Agriculture, 42: 6579.

Keifer, H. H. 1959. Eriophyid studies 27. Occasional Papers, California Department of Agriculture, 1: 1-18.

Keifer, H. H. 1966. Eriophyid studies B-21. State of Bureau of Entomology, California Department of Agriculture, 24pp.

Lindquist, E. E. 1996. External anatomy and notation of structures. In: Lindquist, E.E., Sabelis, M.W. \& Bruin, J. (Eds.), Eriophyoid Mites: their Biology, Natural Enemies and Control. World Crop Pests, 6, Elsevier Science Publishing, Amsterdam, The Netherlands, pp:. 3-31.

Meyer, M. K. 1992. African Eriophyoidea the genus Tetra Keifer 1944 (Acari: Eriophydae). Phytophylactica, 24 (2): 135-143.

Meyer, M. K. and Ueckermann E. A. 1990. African Eriophyidae: genus Aculops Keifer 1966 (Acari: Eriophyidae). Phytophylactica, 22 (2): 159-175.

The Plant List. 2010. Version 1. Published on the Internet. Available from: http://www.theplantlist.org/ (Accessed 29 May 2013)

Xie, M. and Wang, R. 2013. Three new species of the genus Aculops Keifer (Eriophyoidea: Eriophyidae: Phyllocoptinae) from Shanxi Province, China. Entomotaxonomia, 35 (4): $313-$ 320.

Zaher, M. A.; Soliman, Z. R.; Rasmy, A. H.and Abou-Awad, B. A. 1978. Eriophyoid mites of Ègypt. IV Conf. Control. NRG, Cairo: 815-817. 